Будаев А.B.

\title{
ПУБЛИЧНАЯ ДИПЛОМАТИЯ В РОССИЙСКО-БРАЗИЛЬСКИХ ОТНОШЕНИЯХ
}

\begin{abstract}
Аннотация: Цель настоящей статьи - раскрыть особенности российско-бразильских отношений, развивающихся с помощью инструментов публичной дипломатии. Предмет исследования - публичная дипломатия в российскобразильских отночениях.. В отличие от пропаганды, которую ведет государство и его официальные структурь (зачастую это понятие сопряжено с негативными моментами, связанными с дезинформацией и искажением фактов), публичная дипломатия рассматривается как распространение позитивных сведений, основанных на объективном положении дел. Соответственно, эффект и результативность от публичной дипломатии могут быть гораздо больше и долгосрочнее, чем при использовании традиционных пропагандистских методов и приемов воздействия на офиииальную и общественную точку зрения. Несмотря на относительно недавнее введение в научный оборот термина «публичной» или «общественной» дипломатии, отдельные элементы этого явления уже присутствовали на разных этапах внешнеполитической деятельности российского государства. С этой точки зрения представляет интерес анализ опыта использования публичной дипломатии в отнотениях России с Бразилией. $B$ статье делаются выводы о том, что современная публичная дипломатия является важным компонентом мягкой силы, указанной в конщепщии внешней политики России. Ее проводниками являются общественные организащии и институты гражданского общества. Публичная дипломатия в российско-бразильских отнотениях проявляет высокую эффективность потому, что давние традици культурных связей между двумя странами подготовили благоприятную почву для такого формата двусторонних отномений.
\end{abstract}

Review: The purpose of the preset article is to reveal the main peculiarities of the Russian-Brazilian relations being developed by the means of public diplomacy. The subject matter of the research is the public diplomacy in the Russian-Brazilian relations. Unlike propaganda carried on by the government and governmental agencies (quite often the term 'propaganda' has a negative meaning such as disinformation and misinterpretation of facts), public diplomacy is viewed as the dissemination of positive information based on the actual state of affairs. Consequently, the effect and results of public diplomacy can be of more importance and duration than when traditional propaganda methods and techniques of influencing the public opinion are being used. Despite the fact that the term 'public' or 'social' diplomacy has been introduced into scientific use just recently, particular elements of this phenomena have been already present at different stages of the foreign policy activities performed by the Russian state. From this point of view, the analysis of using public diplomacy in the relations between Russia and Brazil is appealing. At the end of his research article the author concludes that today's public diplomacy is the most important component of the 'soft power' indicated in Russia's external policy concept. The conductors of this policy are usually public organizations and civic institutions. In the Russian-Brazilian relations public diplomacy is highly efficient because ancient traditions of cultural ties between these two countries created a fertile ground for such bilateral relations.

Ключевые слова: Международные отночения, политика, право, публичная дипломатия, Россия, Бразилия, мягкая сила, гуманитарное сотрудничество, культурные связи, иенности.

Keywords: international relations, politics, law, public diplomacy, Russia, Brazil, soft power, humanitarian cooperation, cultural ties, values.

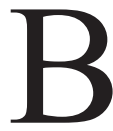
последнее время в международном и российском научных сообществах ведутся активные дискуссии по поводу возрастания роли публичной дипломатии в современных международ- ных отношениях. В сегодняшнем, быстро меняющемся, нестабильном и менее предсказуемом, чем прежде, мире, значение публичной дипломатии, как фактора «мягкой силы» объективно возрастает. В этой свя- 


\section{Политика и общество 2 (110) • 2014}

зи вполне закономерной выглядит поставленная Президентом России В.В.Путиным задача «эффективнее использовать ресурс публичной дипломатии, вовлекать гражданское общество во внешнеполитический процесс» ${ }^{1}$ в целях повышения эффективности и практической отдачи от внешней политики нашей страны.

Основные элементы современной концепции «публичной дипломатии» сформулировал еще в 1965 г. американский политолог, декан Школы права и дипломатии им. А.Б.Флэтчера (при Университете Тафтса) Эдмунд Гуллион. Он писал, что под публичной дипломатией понимаются «средства, при помощи которых правительства, частные группы, отдельные лица меняют установки и мнения других народов и правительств таким образом, чтобы оказать влияние на их внешнеполитические решения» ${ }^{2}$. Согласно Э.Гуллиону, публичная дипломатия имеет дело с влиянием общественных установок на осуществление внешней политики и включает в себя измерения международных отношений, выходящие за рамки традиционной дипломатии (культивирование правительствами общественного мнения в других странах, воздействие на процесс межкультурных коммуникаций).

В различные периоды эволюции двусторонних отношений общественная дипломатия имела ряд особенностей, различную степень интенсивности и охвата. Еще до установления официальных отношений с Бразилией в 1828 г. (во времена колониального господства португальской метрополии) просматривались зачаточные признаки политики, которая впоследствии получила название общественной дипломатии. В ту пору русские первопроходцы посещали южноамериканские страны, включая Бразилию, с научно-познавательными и коммерческими целями. К представителям из России там относились весьма благожелательно. Это было связано с тем, что в отличие от англичан, французов, голландцев, испанцев и португальцев, наши мореплаватели никогда не позиционировали себя в качестве колонизаторов, а торговые дела вели без алчности и жажды к наживе. Так, командир «Благонамеренного» А.П.Лазарев писал: «... мы бываем везде принимаемы с особенной приязнью, какой никто из дру-

\footnotetext{
${ }^{1}$ Указ о мерях по реализации внешнеполитического курса. 7 мая 2012 г. // http://www.kremlin.ru/acts/15256

2 Definitions of Public Diplomacy // http://fletcher.tufts.edu/ Murrow/Diplomacy/Definitions
}

гих наций не пользуется...»³. В качестве курьезного примера доброго отношения к русским людям можно привести выдержу из записки российского вице-консула П.П.Кильхена о «помощи, оказанной бразильским Императором русскому морскому офицеру, упавшему с лошади в Рио-де-Жанейро» ${ }^{4}$.

После победы над Наполеоном русские стали пользоваться еще большей популярностью за границей, включая Бразилию. В донесении на сей счет генконсула России в Рио-де-Жанейро Г.И. Лангсдорфа сообщалось: «Да здравствует Император Александр! Да здравствуют храбрые русские! - восклицают все, знающие, что я русский» ${ }^{5}$.

К ряду убедительных примеров «старой» публичной дипломатии России в Бразилии можно отнести проведение во внутренние районы этой страны в 1821-1829 гг. уникальной экспедиции во главе с бывшим Генеральным консулом России в Рио-де-Жанейро Георгием Ивановичем (Георгом Генрихом) Лангсдорфом с целью изучения местной флоры и фауны, проведения картографических зарисовок. Итогом экспедиции, признанной в мире одним из весомых научных достижений XIX века, стало более 2 тыс. страниц рукописей, дневников, рисунков и карт. Считается, что исследования экспедиции Лангсдорфа до сих пор являются своеобразной «точкой отсчета» для бразильских геодезистов, антропологов, биологов и других специалистов.

В истории российско-бразильских отношений были сложные периоды, когда официальные связи прерывались. Так, в марте 1918 года Бразилия приостановила дипломатические отношения с Советской Россией.

В условиях отсутствия официальных отношений гуманитарные контакты с элементами публичной дипломатии оставались, чуть ли не единственным каналом воздействия на умонастроения бразильских граждан, формирования у них соответствующего образа нашей страны.

В данном контексте исключительное значение принадлежит русскому классическому танцу. Еще в начале прошлого века Бразилия стала пристанищем для некоторых представителей российской артистической богемы. Процесс этот начался с выступлений балетной труппы под руководством С.П.Дягилева с его все-

\footnotetext{
${ }^{3}$ Б.Н.Комиссаров «Русские источники по истории Бразилии первой трети XIX века», издательство Ленинградского университета, 1977 г., стр.10.

${ }^{4}$ Архив внешней политики Российской Империи (далее - АВПРИ), ф.Канцелярия, оп. 468, д.4820, л. 3-4об., копия, фр. яз.

${ }_{5}^{5}$ АВПРИ, ф.Канцелярия, оп. 468, д. 2600, л.5, копия, фр. яз.
} 
мирно известными «Русскими сезонами». В 1920-х гг. известная русская балерина Мария Оленева в ходе продолжительных гастролей по ряду латиноамериканских столиц посетила Рио-де-Жанейро и в итоге связала свою судьбу с этим городом. Она посвятила себя преподаванию классического танца, основав в 1927 г. при Муниципальном театре Рио-де-Жанейро балетную школу, которая и ныне является одним из основных учебных заведений страны по подготовке артистов балета ${ }^{6}$. За 85 лет деятельности школа выпустила десятки танцоров мировой известности и сотни исполнителей классического танца, работающих на различных сценах Бразилии и за рубежом.

Другой здешней бразильской балериной с русскими корнями является правнучка нашего литературного классика Н.С.Лескова - Татьяна Юрьевна Лескова ${ }^{7}$. Во время Второй мировой войны работать в Европе было сложно и основной творческой площадкой для многих артистов стали страны Латинской Америки. В 1944 г. очередные гастроли привели Татьяну Лескову в Рио-де-Жанейро. Балерина планировала поработать здесь полгода, а осталась на всю жизнь. За это время она организовала свою балетную студию, была балериной, а позже директором балетной труппы при Муниципальном театре г. Рио-де-Жанейро. Т.Ю. Лескова объездила практически весь земной шар как самостоятельная танцовщица и как хореограф. Но, пожалуй, ее главное достижение - подготовка более сотни талантливых учеников, которые продолжают нести высокое искусство бразильским и зарубежным зрителям. В 2010 г. в Рио-де-Жанейро состоялась презентация книги бразильской публицистки Сузаны Браги, посвященной жизни и творчеству этой живой легенды российско-бразильского балета. Заметный след

\footnotetext{
${ }^{6}$ В настоящее время школой им. М.Оленевой руководит директор Мария Луиза Норонья, в ней работают 17 педагогов, обучая около сотни детей и подростков. Полный курс обучения составляет десять лет, ежегодно выпускается до 20 профессиональных артистов. В рамках соглашения между школой танца им. М.Оленевой и Академией русского балета им. А.Я.Вагановой (действующего с 2000 г.) в качестве постановщиков-репетиторов несколько лет здесь работали бывшие звезды балета Мариинского театра П.Русанов и М. Вахрушева.

${ }^{7}$ Т.Ю.Лескова родилась в Париже в 1922 г. (семья Лесковых эмигрировала после Октябрьской революции во Францию). Уже в юном возрасте Татьяна вошла в состав труппы Ballets Russes - наследницы легендарного «Русского балета Дягилева». Коллектив Ballets Russes был весьма востребован и гастролировал по многим странам мира.
}

в развитии и пропаганде русской танцевальной школы в Бразилии оставили также Евгения Федорова ${ }^{8}$ и Ноэмия Эдельман ${ }^{9}$. В условиях отсутствия дипотношений между СССР и Бразилией отечественная школа классического танца, как составляющая публичной дипломатии, оказывала благоприятное воздействие на умы и настроения бразильцев.

Только в апреле 1945 г. Бразилиа признала Советский Союз. Установление дипломатических и консульских отношений было оформлено путем обмена нотами. В годы II Мировой войны СССР и Бразилия выступали вместе в антифашистской коалиции, а после победы над гитлеровской Германией стали членами ООН. К сожалению, нормальный ход этих отношений был омрачен осложнением международной ситуации в результате “холодной войны” и противостоянием двух сверхдержав, в результате чего официальные контакты были вновь приостановлены в 1947 году. Лишь в конце 50-х годов прошлого столетия положение стало улучшаться, и в 1961 г. СССР и Бразилия вновь восстановили дипломатические отношения.

\footnotetext{
${ }^{8}$ Е.Федорова начала свою артистическую карьеру в 6 лет в Киевском государственном театре. Во время Второй мировой войны юная балерина была вывезена в Европу для принудительных работ, затем вернулась в профессию на сценах различных балетных школ Германии, Бельгии, Италии. По приглашению хореографа бразильского Далалы Ашкар в 1954 г. она прибыла в Рио-де-Жанейро для преподавания классического танца. Некоторое время балерина была преподавателем-постановщиком в Муниципальном театре Рио-деЖанейро. В ноябре 1959 г. в Муниципальном театре Рио был поставлен полноформатный спектакль «Лебединое озеро», а затем «Баядерка». Балетная академия Федоровой в 1961 г. была преобразована в Бразильский Фонд Балета, открывший множество талантов. Через руки Е.Федоровой прошли тысячи учеников, немалая часть которых стала признанными профессионалами. Обладательница десятков призов, премий и наград, почетная гражданка г. Рио-де-Жанейро (умерла в 2007 г. в возрасте 82 лет).

${ }^{9}$ Н. Эдельман, не являясь русской по происхождению (родилась в Бразилии в семье еврейского эмигранта из нашей страны), сумела пронести любовь и преданность исконно русской культуре через всю свою жизнь и творчество. Балетная труппа под началом Н.Эдельман с 1953 г. в течение 50 лет (до ее смерти в 2004 г.) ставила и исполняла на главных подмостках страны фольклорные танцы с использованием русских национальных костюмов. Талантливый балетмейстер, хореограф и педагог, она последовательно распространяла русскую танцевальную культуру в Бразилии, заслужив признание своих коллег из СССР и России, где она неоднократно бывала. Через ее школу прошло практически три поколения бразильских артистов.
} 


\section{Политика и общество 2 (110) 2014}

В этом плане показательным является визит в Бразилию летом 1961 г. первого космонавта планеты Юрия Алексеевича Гагарина (когда еще официальные отношения отсутствовали). Ю.А.Гагарин, находившийся в поездке на Кубе, получил приглашение прибыть в Бразилию по инициативе ее правительства. По описанию журналиста П.Барашева, самолет с Ю.А.Гагариным прилетел ночью на гражданский аэродром Рио-де-Жанейро, где советского посла мира ждали 120 тыс. человек. Вся дорога к аэропорту была забита людьми, которые размахивали транспарантами и портретами Гагарина... Неповторимая завораживающая улыбка Ю.Гагарина, его легкая простая манера общения покорили сердца жителей Рио-де-Жанейро. Через несколько дней самолет с первооткрывателем космоса приземлился в столице страны г. Бразилиа. Как только Ю.А.Гагарин вышел из самолета и сел в машину, бразильцы подняли автомобиль с ним и несли на руках до президентского дворца. Советский космонавт триумфально находился в Бразилии 2 недели. Он был награжден высшей бразильской наградой для пилотов «Крест заслуженного аэронавта» ${ }^{10}$. Гагарину, как и везде, задавали много вопросов. В частности, его спросили: как он лично может способствовать делу мира? Юрий Алексеевич ответил: «...Один человек ничего не может добиться в столь важном для всей планете деле, как борьба за мир. В ней должны участвовать народные массы всех стран. Только тогда тучи войны будут развеяны навсегда». Примечательно, что уже 23 ноября 1961 г. между СССР и Бразилией были восстановлены дипломатические отношения. Можно предположить, что этому в немалой степени способствовало пребывание в Бразилии Ю.А.Гагарина, активное использование им приемов публичной дипломатии.

Заметное оживление политического диалога, расширение торгово-экономического сотрудничества между странами относится к 1980-ым годам прошлого столетия. В решающей степени это было обусловлено восстановлением в Бразилии в 1985 г. гражданской формы правления и началом демократических преобразований. К этому периоду относится учреждение Бразильско-советского общества дружбы «Убразус», при котором функционировал книжный магазин, пользовавшийся популярностью среди местного насе-

10 Воспоминания о зарубежных поездках Ю.А.Гагарина «Посол мира» http://epizodsspace.airbase.ru/bibl/rossoshan/ fenomen-CD/fenomen4-2.html ления и представителей российской диаспоры благодаря доступным ценам и высокому качеству советских учебников и специальной литературы, переведенных на португальский, испанский и английский языки. ${ }^{11}$ При обществе функционировали курсы русского языка. В деятельности «Убразус», как вспомогательном инструменте советской пропагандистской машины, во многом носивший формальный бюрократический характер, все же просматривались отдельные элементы публичной дипломатии, включая прямой выход на бразильскую общественность.

После распада СССР и установления непосредственно бразильско-российских отношений между нашими странами начался новый этап сотрудничества. Со второй половины 90-х годов Бразилия утвердилась в качестве ведущего делового партнера России в Латинской Америке. Был подписан целый ряд двусторонних документов о сотрудничестве в политической, торгово-экономической, культурной, научной, образовательной и иных областях, осуществлен обмен визитами на высшем и высоком уровнях (в т.ч. визит российского премьера в Бразилию в 2001 г. и посещение России президентом Ф.Энрике Кардо30 в январе 2002 г.). Как отмечает доктор исторических наук, профессор, зав.кафедрой истории истфака Санкт-Петербургского государственного университета Б.Н.Комиссаров, реакция российской общественности не заставила себя ждать. В 2002 г. были основаны региональные общественные организации «Общество дружбы, научного, культурного и делового сотрудничества с Бразилией (Москва) и «Общество содействия научным, культурным и деловым контактам с португалоязычными странами - «Фарол» ${ }^{12}$ (Санкт-Петербург). По сути, речь шла о появлении новых ростков российской публичной дипломатии в отношении Бразилии. Вместе с тем, их деятельность была в определенной степени формальной и имела ограниченный охват.

К публичной дипломатии того периода, очевидно, можно отнести и начало работы в Бразилии, по приглашению руководства местных вузов и научных центров, заинтересованных в привлечении зару-

\footnotetext{
${ }^{11}$ A.А.Жебит «О русской иммиграции и российской общине в городе и штате Рио-де-Жанейро», сборник «Под созвездиями Большой Медведицы и Южного Креста» под редакцией д.и.н. проф. Б.Н.Комиссарова, Санкт-Петербург, 2009 г., с. 15

${ }^{12}$ Б.Н.Комиссаров, статья «К вопросу о реконструкции российско-бразильских отношений в 1828-1889», журнал «Латинская Америка», № 3, 2003 г., с. 56
} 
бежных квалифицированных кадров, российских ученых и преподавателей. Большинство из них оказались здесь без государственного участия и спонсирования, по частной инициативе, занимаясь профессиональной деятельностью в таких бразильских городах как Рио-де-Жанейро, Сан-Пауло, Петрополис, Кампусдус-Гойтаказес. Неся высокую науку в здешние специализированные организации и народные массы, российские физики, математики, конструкторы, инженеры, астрономы, врачи снискали и до сих пор пользуются заслуженным авторитетом и уважением.

В августе 1994 г. благодаря деятельности инициативной группы из представителей местной российской диаспоры, поддержанной российскими диппредставительствами в Бразилии, был учрежден Бразильскороссийский институт культуры им. М.Ю.Лермонтова (ИКЛ $),{ }^{13}$ который также стал одним из проводников отечественной публичной дипломатии. В качестве приоритетов деятельности Института утвердились литературно-музыкальное и культурное просвещение, организация лекций, концертов, выставок и вечеров, посвященных памяти творчеству А.С.Пушкина, М.Ю.Лермонтова, Ф.М.Достоевского, А.П.Чехова, П.И.Чайковского, Н.А.Римского-Корсакова, С.С.Прокофьева, Д.Д.Шостаковича и других российских классиков. Постепенно ИКЛ эволюционировал в один из основных центров притяжения для нашей диаспоры, завоевал популярность среди бразильской и российской общественности.

Другой составляющей российской публичной дипломатией в Бразилии оставалось присутствие и распространение здесь русского классического танца. В этой связи необходимо упомянуть Школу Большого театра (ШБТ) в Жоинвилле (небольшом городе на юге Бразилии), которая начала свою деятельность 15 марта 2000 г. В настоящее время в жоинвилльской Школе ${ }^{14}$ обучаются 260 детей из многих штатов Бра-

13 Президентом института был избран (ныне покойный) Жеова ди Арруда Камара, журналист, антрополог и музыкальный критик. В актив ИКЛ также вошли наши соотечественники Сержио Паламарчук, Александр Медведовский, представители местных культурных и артистических кругов Мириам Дауэлсберг, Наталия Тиндберг, Нелсон Меллудэ-Соуза, Анита Гордич, бывший посол Бразилии в СССР С.П.Ногейра.

${ }^{14}$ Общая площадь Школы Большого театра составляет более 6000 квадратных метров, куда входят 11 залов для балета, 10 классов для занятий фортепиано, классы для теоретических занятий, административные помещения, столовая и кон- зилии, а также ряда соседних латиноамериканских стран. Большинство учеников - выходцы из бедных слоев населения, 95 \% из них обучается бесплатно, что делает этот проект уникальным по своему социальному содержанию. В рамках празднования в 2010 г. 10-летия основания балетной Школы в ряде городов страны с успехом прошли спектакли учеников этого учебного заведения. Всего за этот период на спектаклях ШБТ побывали более 300 тыс. бразильцев, и еще 45 тыс. человек посетили здание Школы в Жоинвилле. Бразильские ученики выступали с гастролями в Уругвае, Италии, Франции, Германии. Важная роль, которую ШБТ в Бразилии играет в развитии двухсторонних отношений, неоднократно отмечалась президентами России и Бразилии В.В.Путиным и Л.Лулой.

На нынешнем этапе наши государства успешно развивают стратегическое партнерство как на двусторонней основе, так и в многосторонних форматах, прежде всего в рамках - БРИКС, «Группы 20». Их связи стали более глубокими, насыщенными и диверсифицированными. Нынешняя ситуация формирует благоприятные предпосылки для активного задействования публичной дипломатии в российско-бразильских отношениях.

Важным направлением в продвижении отечественной публичной дипломатии в Бразилии является задействование российских неправительственных организаций (НПО). В последние годы в нашей стране сформировалось несколько десятков НПО, в т.ч. занимающихся международными проблемами. Среди них: Общественная палата, Совет по внешней оборонной политике, Центр политических исследований России, Фонд поддержки публичной дипломатии им. А.М.Горчакова, Фонд русский мир и др. Так, в Международной конференции ООН по устойчивому развитию «Рио+20» (Рио-де-Жанейро, 13-22 июня 2013 г.) принял участие целый ряд российских общественных и неправительственных организаций, которые провели полезную работу по продвижению российских подходов к указанной проблематике и укреплению позитивного образа России в деятельности на природоохранном направлении.

цертный зал. В Школе работают бразильские и российские педагоги, четверо из которых являются бывшими артистами Большого театра России. Регулярно проводятся совместные концерты с ведущими солистами Большого театра; ежегодно наиболее талантливые ученики Школы проходят стажировку в Большом театре. 


\section{Политика и общество 2 (110) • 2014}

Группа членов Общественной палаты Российской Федерации ${ }^{15}$ 13-18 июня 2012 г. участвовала в заседаниях Президиума Международной ассоциации экономических и социальных советов и схожих институтов (МАЭСССИ), в сессиях МАЭСССИ и «круглом столе» ОП РФ и МАЭСССИ.

Представители Российской ассоциации содействия $\mathrm{OOH} \mathrm{(РАС} \mathrm{ООН),} \mathrm{включая} \mathrm{зампредседателя} \mathrm{РАС}$ ООН, завкафедрой ЮНЕСКО МГИМО (У) МИД России А.Н.Борисова, 18-22 июня 2012 г. подключились к работе по официальной программе форума «Рио+20».

Делегация Института Питирима Сорокина и Николая Кондратьева во главе с его президентом, доктором экономических наук, профессором Ю.В.Яковцом (и в составе 14 человек) 13-19 июня 2012 г. приняла участие в 6-ом Цивилизационном форуме по тематике: «Долгосрочная стратегия устойчивого развития, основанная на партнерстве цивилизаций: концепции, программы и проекты».

Руководство общественной организации Ноосферная духовно-экологическая Ассамблея Мира НДЭАМ (ее президент, доктор философии, заслуженный деятель культуры России Л.С.Гордина и еще три человека) 14-19 июня 2012 г. участвовало в рамках форума «Рио+20» в мероприятиях к 150-летнему юбилею В.И.Вернадского, включая конференцию «Ноосферная парадигма развития мировой цивилизации в XXI веке. Глобальная стратегическая инициатива мирового гражданского сообщества».

Еще одной перспективной идеей представляется формирование стратегического партнерства между парламентами России и Бразилии при участии гражданского общества и НПО. 21 июня 2012 г. «на полях» саммита «Рио+20» состоялись встречи первого вице-президента Палаты депутатов Национального конгресса Бразилии Р. де Фрейтас и председате-

\footnotetext{
${ }^{15}$ Общественную палату РФ представляли: ее секретарь Е.П. Велихов; 1-ый замсекретаря ОП М.В.Островский; председатель комиссии ОП по развитию гражданского общества и взаимодействию с общественными палатами субъектов Российской Федерации И.Е. Дискин; руководитель межкомиссионной рабочей группы ОП по международному сотрудничеству и общественной дипломатии, член комиссии по развитию гражданского общества и взаимодействию с общественными палатами субъектов Российской Федерации А.В. Соколов; директор Института устойчивого развития ОП В.М. Захаров; помощник руководителя аппарата ОП, начальник пресс-службы М.В.Рыклина; замначальника отдела международных связей аппарата ОП Я.Г.Колодин
}

ля Комитета по международным делам и национальной обороне нижней палаты парламента П.Алмейда с руководителем межрегиональной общественной благотворительной организации (МОБО) «Парус надежды» Л.Н.Зеленцовой. В ходе состоявшегося обмена мнениями отмечалась целесообразность подключения гражданских обществ двух стран к стратегическому партнерству как на двустороннем уровне, так и в формате БРИКС. Участники переговоров условились предпринять совместные параллельные шаги в целях продвижения и конкретизации данной инициативы. Важно, чтобы за «бортом» формирующегося на основе инициативы МОБО «Парус надежды» делового сотрудничества (под предлагаемым общим названием «Альянс стратегического партнерства БРИКС-НПО») не остались другие заинтересованные российские неправительственные организации, например, Общественная Палата Российской Федерации. В любом случае, главной «несущей конструкцией» будущего партнерства, очевидно, должен стать именно парламентский сегмент.

В этом же ключе следует рассматривать налаживающиеся сотрудничество по линии Открытых правительств (ОП) России и Бразилии. В 2012 г. в г. Бразилиа состоялись рабочие поездки Министра РФ М.А.Абызова и других представителей российского ОП с целью налаживания взаимополезного сотрудничества с бразильскими коллегами в сфере содействия совершенствованию системы госуправления. В центре внимания переговоров находились вопросы взаимодействия власти с экспертным сообществом, развития НКО, внедрения концепции «Открытых данных» и другие темы.

Вместе с тем, отмеченные выше контакты с участием общественных и неправительственных организаций двух стран носит пока спорадический характер, страдают отсутствием четко сформулированных задач и стратегии их реализации. В данном контексте представляется весьма важным анализ и обобщение имеющегося опыта в этой сфере, определение наиболее приоритетных направлений сотрудничества, включая поддержку «головных» российских организаций и НПО с целью перевода такой работы на плановую системную основу.

Трудно не согласиться с мнением доктора исторических наук А.В.Лукина о том, что в интересах активизации публичной дипломатии целесообразно по примеру других стран назначить должностное лицо или ведомство, которое координировало бы 
ее на общегосударственном уровне. ${ }^{16}$ В нашем случае стоило бы подумать над идеей наделения соответствующими полномочиями Россотрудничества. В пользу этого свидетельствуют и планы открытия в обозримом будущем в ключевых бразильских городах (сначала Сан-Паулу, затем Бразилиа и, возможно, Рио-де-Жанейро) российских центров науки и культуры, которые призваны стать передовыми форпостами распространения русского языка, культуры, традиций и т.д.

Что касается публичной дипломатии Бразилии, то она лишь начинает пробивать себе дорогу. Концепция внешней политики Бразилии до сих пор находится в стадии разработки. Хотя, по имеющимся данным, в этом труде будут отражены общие задачи по продвижению общественной дипломатии. В другом, весьма объемном (свыше трехсот страниц), документе, т.н. директивных направлениях развития внешней политики Бразилии, эта политика затрагивается вскользь. При этом в последние годы в ряде научных статей и публикаций бразильских политологов, дипломатов и ученых все чаще делаются ссылки на публичную дипломатию, актуальность ее использования при продвижении национальных интересов и укреплении имиджа страны. Так, бразильский политолог Миорандо Бернардо Сфредо в своей работе признает, что «у Бразилии есть огромный потенциал в плане развития публичной дипломатии, которая способна все больше применять «мягкую силу» в формировании международной роли страны. Считается, что опыт первого периода правления экспрезидента Л.Лулы (2003-2007 гг.- примеч. автора) может продемонстрировать, что Бразилия находится в той ситуации, когда она может извлечь значительные преимущества от применения прочной публичной дипломатии. Стоит, однако, обратить внимание на предположение о том, что существуют различные инициативы бразильской публичной дипломатии, которые не рассматриваются с надлежащей серьезностью, поскольку не признается их реальная важность... в отличие от других сфер, не существует единой объективной и консолидированной политики по продвижению образа Бразилии в глазах иностранной общественности. Публичная дипломатия является молодым понятием, а потому заслуживает дополни-

16 А.В.Лукин, статья «Публичная дипломатия», журнал «Международная жизнь», № 3, март 2013, c.85, http://dlib. eastview.com/browse/doc/29172846 тельного обсуждения, так как литературы по данному вопросу мало, особенно в Бразилии» ${ }^{17}$.

Авторский коллектив в составе Карлуша Аурелио Пименты де Фариа и Жоаны Лауры Маринью Ногейра отмечает ощутимое расширение публичной дипломатии в период правительства Л.Лулы (2003-2011 гг. - примеч. автора), не только с точки зрения проецирования образа Бразилии за рубежом, но и в плане распространения задач национальной внешней политики внутри страны. Именно второй аспект бразильской публичной дипломатии они ассоциируют с созданием специального канала МИД Бразилии на видеохостинге youtube (http://www.youtube.com/mrebrasil), где имеется доступ к видео и аудио-программам, интервью главы бразильского внешнеполитического ведомства, других дипломатов и представителей официальных властей по тематике внешней политики ${ }^{18}$.

Публичная дипломатия Бразилии продолжает развиваться и после 2011 г. при новом президенте Дилме Роуссефф, которая стала первой президентом-женщиной в истории Бразилии. Через научно-исследовательские центры, общественные и неправительственные организации Бразилия позиционируется как один из лидеров развивающихся экономик, государство, ратующее за устойчивое развитие, сочетающее сбалансированный экономический рост с охраной окружающей среды. Все большее число сторонников, особенно среди латиноамериканских соседей, завоевывает прагматическая (по сути, социал-демократическая) модель развития Бразилии, демонстрирующая приемлемые экономические показатели при реализации социально ориентированных программ.

Применительно к бразильской публичной дипломатии в отношении России наиболее распространенными формами ее применения являются различные общественно-политические и культурные мероприятия, включая демонстрацию в нашей стране широко известных бразильских телевизионных сериалов ${ }^{19}$,

\footnotetext{
${ }^{17}$ Миорандо Бернардо Сфредо, статья «Культурная дипломатия как инструмент бразильской внешней политики», Лейла Бейшус, Вероника Арруда, с. 53

18 «Межправительственная координация для осуществления бразильской внешней политики», статья, 2012, Карлуш Аурелио Пимента де Фариа, Жоана Лаура Маринью Ногейра

19 Бразильские теленовеллам, снискали в нашей стране огромную популярность с выходом на телеэкраны в 1988 г. широко известного сериала «Рабыня Изаура». После этого около двадцати бразильских телевизионных саг приковывали внимание российских телезрителей.
} 


\section{Политика и общество 2 (110) • 2014}

организацию фестивалей современного бразильского кино ${ }^{20}$, выставок живописи и т.д. К публичной дипломатии Бразилии, очевидно, можно отнести и такие бразильские явления как всемирно известный и набирающий с каждым годом большую популярность (в т.ч. среди россиян) Карнавал, а также футбол. В последние годы несколько маститых бразильских футболистов с успехом выступают в российской футбольной Лиге ${ }^{21}$. В нашей стране имеется немало поклонников бразильского футбола, даже есть объединение фанатов самой популярной в Рио-де-Жанейро команды «Фламенго», имеющих свой собственный сайт. И это, безусловно, тоже одно из проявлений бразильской публичной дипломатии.

Возвращаясь к российской публичной дипломатии, можно констатировать, что ее возможности на бразильском и, в целом, южноамериканском направлениях, к сожалению, востребованы далеко не полностью, при очевидной значимости и перспективности потенциала. Предстоит существенная работа по определению оптимального формата и алгоритма действий по реализации российских интересов в Бразилии через ресурсы публичной дипломатии. Более активное задействование публичной дипломатии могло бы гармонично дополнить общегосударственные усилия по продвижению российских позиций в этом ведущем латиноамериканском государстве, стать ориентиром, своего рода «пилотной» программой для политики России в отношении других стран Южной Америки.

\section{Библиография:}

1. Указ о мерах по реализации внешнеполитического курса. 7 мая 2012 г. // http://www.kremlin.ru/acts/15256

\footnotetext{
${ }^{20}$ С 9 по 15 октября 2013 г. в московском кинотеатре 35мм в шестой раз прошел фестиваль бразильского кино. В этот раз в программу кинофестиваля вошли девять картин фильмов о семье, музыке и жизни современных бразильцев (http://kinocccp.net/news/2013-10-09-61)

${ }^{21}$ Речь идет о Вагнере Лаве, который в 2004-2011 гг. играл в качестве форварда за московский ЦСКА. С 2009 г. другой бразильский футболист Рафаель Кариока из команды «Васко да Гама» (г.Рио-де-Жанейро) выступает за «Спартак» (г.Москва), a c 2010 г. голкипер кариокского «Флуминенсе» Маркес Майкон защищает цвета московского «Локомотива». В 2011 г. с популярным футболистом Роберто Карлосом подписал контракт клуб «Анжи» (г.Махачкала), за который он играл в качестве левого защитника и являлся капитаном команды.
}

2. Definitions of Public Diplomacy // http://fletcher. tufts.edu/Murrow/Diplomacy/Definitions

3. Комиссаров Б.Н. Русские источники по истории Бразилии первой трети XIX века, издательство Ленинградского университета, 1977 г.

4. Архив внешней политики Российской Империи, ф.Канцелярия, оп. 468, д.4820, л. 3-4об., копия, фр. яз.

5. Архив внешней политики Российской Империи, ф.Канцелярия, оп. 468 , д. 2600 , л. 5 , копия, фр. яз.

6. Воспоминания о зарубежных поездках Ю.А. Гагарина «Посол мира» http://epizodsspace.airbase. $\mathrm{ru} / \mathrm{bibl} / \mathrm{rossoshan} /$ fenomen-CD/fenomen4-2.html

7. Жебит А.А. О русской иммиграции и российской общине в городе и штате Рио-де-Жанейро, сборник «Под созвездиями Большой Медведицы и Южного Креста» под редакцией д.и.н. проф. Б.Н.Комиссарова, Санкт-Петербург, 2009 г.

8. Комиссаров Б.Н. К вопросу о реконструкции российско-бразильских отношений в 1828 1889, журнал «Латинская Америка», № 3, 2003 г., c. 56.

9. Лукин А.В. Публичная дипломатия», журнал «Международная жизнь», 2013, № 3, с.85, http://dlib.eastview.com/browse/doc/29172846

10. Миорандо Бернардо Сфредо, Культурная дипломатия как инструмент бразильской внешней политики, Лейла Бейшус, Вероника Арруда, с. 53.

11. Карлуш Аурелио Пимента де Фариа, Жоана Лаура Маринью Ногейра. Межправительственная координация для осуществления бразильской внешней политики. 2012.

\section{References (transliteration):}

1. Komissarov B.N. Russkie istochniki po istorii Brazilii pervoi treti XIX veka, izdatel'stvo Leningradskogo universiteta, $1977 \mathrm{~g}$.

2. Zhebit A.A. O russkoi immigratsii i rossiiskoi obshchine $\mathrm{v}$ gorode i shtate Rio-de-Zhaneiro, sbornik «Pod sozvezdiyami Bol'shoi Medveditsy i Yuzhnogo Kresta» pod redaktsiei d.i.n. prof. B.N.Komissarova, Sankt-Peterburg, $2009 \mathrm{~g}$. 
3. Komissarov B.N. K voprosu o rekonstruktsii rossiisko-brazil'skikh otnoshenii v 1828-1889, zhurnal «Latinskaya Amerika», № 3, 2003 g., s. 56.

4. Lukin A.V. Publichnaya diplomatiya», zhurnal «Mezhdunarodnaya zhizn’», 2013, № 3, s.85, http:// dlib.eastview.com/browse/doc/29172846
5. Miorando Bernardo Sfredo, Kul'turnaya diplomatiya kak instrument brazil'skoi vneshnei politiki, Leila Beishus, Veronika Arruda, s. 53.

6. Karlush Aurelio Pimenta de Faria, Zhoana Laura Marin'yu Nogeira. Mezhpravitel'stvennaya koordinatsiya dlya osushchestvleniya brazil'skoi vneshnei politiki. 2012. 